\title{
Horas de mudanças, evocações e agradecimentos
}

\author{
Harley E. A. Bicas
}

Em 26 de novembro, o C.B.O. inaugurava sua nova sede, à Rua Casa do Ator, 1.117, na Vila Olímpia, em São Paulo, deixando sua casa já tradicional, na Alameda Santos, 1.343, onde estava desde 1992. A leitura sobre essa mudança traduz-se com um significado inequívoco. O do dinamismo da instituição que, sem deixar de lado todos os cuidados para com o ensino da Oftalmologia e a sua boa prática, sem se afastar da continuada preocupação e luta na promoção da saúde ocular e visual de nossa gente e sem negligenciar a busca de todos os complementos necessários para manter viva, alerta e atuante a unidade de nossa especialidade; enfim, sem deixar de crescer no respeito e na consideração de seus membros e de toda a nação, ainda mostra forças para o desenvolvimento material. Uma parte da liquidez financeira do C.B.O., diligentemente amealhada por várias gerações e resultado de cuidados gerenciais de seus administradores, é assim imobilizada, como mais uma garantia patrimonial e econômica sua, para orgulho de todos nós e como referência explícita a que, até nas demonstrações exteriores de poder, a Oftalmologia brasileira se sobressai.

Com respeito a patrimônio, e embora a circunstância seja meramente acidental, os Arquivos Brasileiros de Oftalmologia mudam, não apenas de endereço mas, também, de condutor. E já era mais que hora, pois, afinal, são agora dez anos em que venho ocupando essa responsabilidade. Volto a exemplares passados para o registro de que meu comprometimento mais formal com os Arquivos é ainda mais antigo; remonta a 1981 quando, já chefe de meu Departamento de origem e assumindo o cargo de seu Professor Titular, passei a integrar a lista de seus Redatores (volume 44, n 2). Em 1990 fui altamente distinguido pela ascensão ao seleto grupo do então chamado Conselho Editorial (hoje equivalente ao de Editores Associados) e, em 1996, à Editoria Científica, com Rubens Belfort Mattos e Rubens Belfort Mattos Júnior. Em seguida, apenas com este, em 1998 e 1999, embora ele fosse, efetivamente, o verdadeiro responsável por toda a produção da revista. Mesmo assim o susto foi grande quando, em setembro de 1999, no jantar em homenagem aos palestrantes do XXX Congresso Brasileiro de Oftalmologia, em Recife, Rubens Belfort Júnior, por razões de assumir novos e mais exigentes compromissos, comunicava-me sua intenção de me passar, integralmente, toda a responsabilidade pela editoração da revista. Enorme honra pois, até então, essa função sempre fora exercida por um Belfort Mattos: ele, em sequência a Rubens, seu pai, por sua vez sucessor de Waldemar, o avô, fundador.

Sinto-me orgulhoso por haver sido elemento nessa transição da revista, ao tomar a providência, como uma de minhas primeiras na chefia editorial, de formalizar a passagem oficial desse patrimônio da Oftalmologia brasileira ao C.B.O. (embora este já considerasse os Arquivos como seu órgão científico e mantivesse sua publicação desde 1977 - cf. vol. 40, nº 4). Outras vitórias da revista puderam ser comemoradas durante esse tempo. Mas já são, agora, dez anos à frente dela, o que significa, mais do que conveniência, uma absoluta necessidade de que um novo comando lhe seja dado. Talvez, aliás, a duração desse mandato tenha sido demasiada. Amigos, gentilmente, protestarão dizendo que a revista cresceu muito durante esse tempo. É verdade. Como, entretanto, teria também crescido, e talvez ainda mais, se fosse com outras propostas. Pois é, afinal, a própria grandeza dessa nossa Oftalmologia que a impulsiona - e sempre mais - para novas conquistas que, inexoravelmente, virão. Contento-me em pensar que combati o bom combate, completei minha jornada, guardei a fé; essa fé na pujança da Oftalmologia brasileira, sempre grande e cada vez maior. E o fiz com o melhor que eu pudesse ter dado, em atitude de serviço e retribuição à especialidade que tanto me proporcionou.

De qualquer modo, com a clara consciência de minhas limitações e de que os progressos decorreram de conjunturas favoráveis, como a do expressivo aumento da oferta de publicações científicas no Brasil e a dos contínuos saltos de qualidade de nossa ciência oftalmológica e em sua prática, avulta-me, igualmente, a noção de que nenhum crescimento teria sido possível sem o concurso dos dedicados protagonistas das equipes de apoio, desvelados em propiciar seus preciosos tempos e talentos à revista. E - apesar das sempre perigosas omissões ao mencionar pessoas que mais intensamente trabalharam, distinguindo-as das que trabalharam muito e das que "apenas" trabalharam - não é aconselhável deixar de correr o risco para, efusivamente, agradecer às que estiveram quase todo esse tempo conosco, desde as primeiras horas. Como Mauro Goldchmit, Samir Jacob Bechara e Vital Paulino Costa, que se juntam aos que até agora permanecem, Cristina Muccioli, Mauro Silveira de Queiroz Campos e Paulo Elias Correa Dantas. E à laboriosa equipe de retaguarda, Paulo Mitsuru Imamura, Edna Terezinha Rother, Maria Elisa Rangel Braga e Hanna Rotschild (in memoriam), com a assessoria cotidiana e incansável de Claudia Moral e Claudete Nagem Moral.

Assim, pela paciência para com as insuficiências de coordenação, e pela superação decisiva delas, por meio da dedicação e apoio à causa da revista, agradeço a todos, carinhosamente. E, sobretudo, pelas oportunidades de vivenciarmos, juntos, esse período de serviço e de amor à nossa Oftalmologia.

Obviamente, continuarei a reverenciar essa revista, mais do que qualquer outra. Pois, parafraseando Fernando Pessoa, essa revista de minha aldeia não é a melhor revista do mundo, mas é a revista de minha aldeia. 